\title{
VOCABULARY LEARNING STRATEGIES OF GOOD LANGUAGE LEARNERS FROM AN INTERNATIONAL SCHOOL
}

\author{
Syafiqah Hasram \\ Education Faculty \\ Universiti Kebangsaan Malaysia \\ Malaysia \\ syafiqahasram@gmail.com \\ Belvinna Kaur Ajaib Singh \\ Education Faculty \\ Universiti Kebangsaan Malaysia \\ Malaysia \\ vinnakaur@gmail.com
}

\author{
DOI: 10.31364/SCIRJ/v9.i02.2021.P0221843 \\ http://dx.doi.org/10.31364/SCIRJ/v9.i02.2021.P0221843
}

\begin{abstract}
In the era of globalisation, English has become an essential aspect of life. People throughout the world have recognised how important the English language is in the education system. Schools all over the world have implemented English in Mathematics and Science learnings. In Malaysia, many international schools are now open, and parents are sending their children to these schools in order for them to have the fluency of the English language. Despite being non-native speakers, many students have successfully gained strong language proficiency in the English language. This paper aims to look at the successful strategies used by secondary learners in an international school in acquiring vocabulary. The participants in this study were 30 students from an international school based in Selangor state. The data was collected through questionnaires and the findings were analyzed. The data was based on quantitative research. The findings were focused on the language learning strategies to acquire vast vocabulary knowledge. The findings were then used to conclude how successful language learners improve their vocabulary in learning English.
\end{abstract}

Index Terms: Language learning strategies (LLS), international school, vocabulary, language proficiency

\section{INTRODUCTION}

In today's world, the global spread of English is unparalleled. English plays a role in building communication and it is the second language in many nations. English in the education system plays a massive role in preparing the learners for a better future in the globalisation era. Learners are exposed to language learning through various ways, such as watching movies, reading books written by native speakers, and surfing the internet. Teachers recommend different methodologies for students to improve their language skills. In many schools, teachers are sent for training to improve their knowledge and pedagogical methods to convey the language's content effectively.
Similarly, international schools' teachers are sent for training to sharpen their skills and knowledge. The four main elements of the English language are writing, speaking, listening and reading skills. To become a successful language learner, one has to master all language skills.

As one of the fundamental skills in language, [1] suggest that vocabulary is like building blocks of language. Without sufficient vocabulary, learners are more likely to face difficulties in learning other aspects of language. Vocabulary knowledge is a benchmark of proficiency in writing, reading, listening and speaking [2]. Without ample vocabulary knowledge, learners are more likely to struggle in comprehending verbal communication, express their opinions and ideas, and follow written instructions. While other language elements like grammar are undoubtedly important, [3] believes it is not a vital part of the language.

In most cases, learners can still communicate and get their message across even without following grammar rules. However, without words, it is almost impossible for one to express themselves. Teaching words is crucial in learning a language as languages are based on words [4].

21 st-century education is about empowering students with the skills and strategies they need in this rapidly changing world. [5] suggests that language learners who have greater control of their learning will become more successful than those who do not. In addition to language teaching methodology, learning strategies notably enable learners to boost their learning of another language. Language learning has to be [6] defines language learning strategies (LLS) as the problem-solving mechanisms or techniques used by learners to cope with the complex learning process. Many related studies explore language learning strategies, but there are limited findings in an international school context. 


\section{A. Background of the Study}

1) Vocabulary learning for Malaysian English as Second Language (ESL) learners

Vocabulary knowledge in second language learning is imperative in acquiring competence and mastery in the language. Vocabulary is a vital component of language communication, as supported by [7] that a vast vocabulary repertoire is necessary to help learners understand verbal and written communication. [4] Alqahtani found that second language learners rely heavily on their vocabulary knowledge in comparison to other language skills.

Recognizing the importance of vocabulary knowledge in acquiring language, Malaysian teachers and language practitioners start building the students' vocabulary from a young age. Nonetheless, past studies indicate that ESL learners in Malaysia are weak in vocabulary acquisition. A previous study by Ashrafzadeh \& Nimehchisalem [3] found that over $97 \%$ of Malaysian tertiary learners only achieved 'fair to poor' on their vocabulary scores based on their performance in the summary writing task. Nor Hazwani et al.[8] in her result reveals that the majority of the students failed to reach the mastery level for vocabulary.

\section{2) Language learning strategies for ESL learners}

The gradual shift from teacher-centered classrooms to a more dynamic learner-centered learning calls for a need to develop autonomy among ESL learners. Teachers are no longer considered the sole source of knowledge; thus, LLS is significant in facilitating ESL learners' independence in learning. Noor Zainab \& Babikkoi [9] reveals that LLS encourages learners to take charge of their learning. It plays a prominent role in facilitating understanding in second language learning.

In a study among secondary school students, Noor Azliza [10] found that LLS promoted understanding in reading comprehension, one of the language skills in the Malaysian English syllabus. Since learners are a big part of autonomous learning, investigating learners' effective LLS is as effective. Mohamed Amin et al. [11] supports that understanding students' language learning process and how it affects language success is vital in assisting students in learning the English language.

\section{3) International schools in Malaysia}

The English language has always been the primary focus in international schools. The number of international schools in Malaysia is increasing in the past few years. The international schools are often branded as role models in English language proficiency as the majority of the subjects are taught in English. Nonetheless, the English teachers in the international schools are mostly native speakers hired to deliver the subject's content.

In most international schools, vocabulary is being developed from a young age and throughout their schooling years. Since vocabulary is the core component of language proficiency, vocabulary learning is the highlight of several lessons in English class. Lessons of other skills would coincide with vocabulary learning as knowing the meaning of the terms would provide much of the basis for how learners speak, listen, read and write. The vast improvement in learners' English language acquisition throughout their schooling years in international schools are undeniable. Thus, this paper investigates the effective language learning strategies employed by secondary international school students in vocabulary learning.

\section{B. Research Objektives \& Questions}

This study investigates the language learning strategies employed by good language learners from an international secondary school, specifically in their vocabulary skills. The study will answer the following question:

- What are the strategies employed by good language learners of the international school in acquiring vocabulary?

- How do learners apply the strategies in their vocabulary learning?

Research objectives:

- To investigate the strategies employed by good language learners of the international school in acquiring vocabulary.

- To explore ways learners apply the strategies in their vocabulary learning.

The study's findings enable learners to be aware of various language learning strategies and strategies that enhance their learning. It also helps teachers design English lessons to incorporate suitable language learning strategies to improve students' English language skills.

\section{LITERATURE REVIEW}

\section{A. Definitions of the concept}

The process of learning requires an adaptation of strategy to achieve its purpose. Learning strategy is drawn from the two main concepts, which are learning and strategy. Human beings use multiple strategies in learning. However, not all of them yield success. The term language learning strategies is defined by Oxford [12] as "specific actions taken by the learner to make learning easier, faster, more enjoyable, more selfdirected, more effective and more transferable to new situations." LLS is learning skills, learning-to-learn skills, and problem-solving skills. The use of strategies in learning results in learners becoming active in their learning (Susanto et al., 2019); thus, assuming responsibility to manage their learning independently. In addition, Martinez [6] suggests that strategies are flexible. It can be taught and learners can be trained in their management. Consequently, learners shall be made aware of their strategies and train in their practice.

Learning strategies in vocabulary learning can be interpreted as mastering new vocabulary to the learners' needs and preferences. Thus, the application of appropriate LLS in vocabulary learning may contribute to successful vocabulary acquisition. Vocabulary learning is a lifelong task of learning languages [13]; learners continue to discover new words even after being considered fluent in the language. By training learners with appropriate LLS, learners can build their independence and skills to master new words. According to Cameron [14], vocabulary learning strategies are actions applied by learners to help them comprehend and memorize vocabulary items obtained throughout their language learning experience.

\section{B. Classification of LLS}

Language learning strategies are believed to indicate learners' successful language learning, with some strategies being more successful than others. There are several classifications of language learning strategies. This study 
classifies LLS based on Oxford [12], which divides LLS into two main categories; direct and indirect strategies.

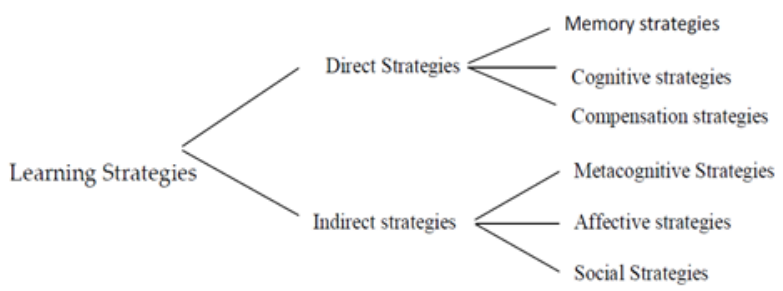

Fig. 1. Learning Strategies

\section{1) Direct strategies}

Direct strategies require mental processing of the newly learned language. It benefits learners by assisting learners in storing and recovering information when needed. The strategies also aid learners in understanding and use the new knowledge.

\section{a) Memory strategies}

Memory strategies are frequently used at the beginning of language learning. Learners apply the strategies by associating words and phrases with visual images, sounds, smell, motions, or touch. The strategies consist of four sets that include:

- Creating mental linkages

- Applying images and sounds

- Reviewing well

- Employing action

b) Cognitive strategies

Cognitive strategies are probably the most popular strategies with language learners. It usually entails conscious use of target language, which involves identifying, retaining, storage, and retrieval. This strategy falls into four sets which are:

\section{- Practicing}

- Receiving and sending messages

- Analysing and reasoning

- Creating structure for input and output

c) Compensation strategies

Compensation strategies are beneficial to learners in handling their limited knowledge. The strategies enable learners to use language despite knowledge gaps. Learners use compensation strategies when they have insufficient knowledge of the target language grammar and vocabulary. The strategies include are:

- Guessing from the context

- Overcome limitations in speaking and writing

\section{2) Indirect strategies}

Indirect strategies are metacognitive, affective and social strategies. These strategies help learners regulate language learning by providing indirect support for language learning by employing focusing, arranging, evaluating, seeking opportunities, and lowering anxiety.

\section{a) Metacognitive strategies}

Metacognitive strategies are concerned with how learners learn. These strategies allow learners to coordinate their learning through planning, monitoring, evaluating and modifying. When learners face difficulties with vocabulary, language rules, or writing systems, these strategies become vital for successful language learning. Three sets belong to the strategies, which are:
- Centre learning

- Arrange and plan learning

- Evaluate learning

b) Affective strategies

These strategies are concerned with learners' emotional requirements. They help students manage their motivation, attitudes associated with learning [15] and decreasing anxiety levels, especially during communication. An appropriate amount of anxiety could help ensure learners' optimum capability. However, too much anxiety may hinder learning. The strategy groups include:

- Lowering anxiety

- Encouraging self

- Taking emotional temperature

\section{c) Social strategies}

Social strategies advocate learning independence and aid learners to practise the knowledge gained. Teh, Yusoff \& Embi [16] states that social exposure through collaborative learning is vital to language learning. It allows learners to work together to achieve goals, have the freedom to be creative, and have a mutual understanding with their group members. The strategies include:

- Asking questions

- Cooperating with others

- Empathizing with others

\section{Good Language Learners}

Good language learners often associated themselves with strategies and techniques that are crucial for improving their language skills. Many strategies are linked with good language learners. Usually, good language learners will experiment with strategies and choose the best one that suits their needs and level. A good language learner does not necessarily come from a native speaker. English falls into the second language category for some people, and the learners often improve themselves to perform better. Since English is known as an international language, many learners take the initiative to improve their vocabulary. In the international school, learners are divided into classes depending on their credibility. Hence, many learners will try to become good English speakers in order to be in the first class.

According to Sewell [17], good language learners impose interest in learning the language through building a relationship between the vocabulary. Interest is also one of the most essential characteristics in learning a second language. For this reason, it is vital to carry out research on which strategies play a role in improving vocabulary. A good learner represents the use of the language and proper strategies that lead to proper vocabulary acquisition.

\section{METHODOLOGY}

This study aimed to identify language learning strategies employed by good language learners and explore how learners apply the strategies in their learning processes. The research design for this study is mixed-method. The mixed-method approach combines quantitative and qualitative research techniques within the same study [18]. Two data collection procedures are employed to collect both quantitative and qualitative data for this study. Quantitative data is collected using a survey, while an interview is adopted to gather qualitative data. 


\section{A. Sample of The Study}

The study sample was determined by using non-probability sampling, where the group of good language learners was chosen by purposive sampling. Thirty participants of good language learners from an international school in the Selangor state were selected from the study. The participants were exposed to learning English as young as three years old and have spent their education years in an international school for the past eight to nine years. The learners belong to the age group of 15 to 17 years old. The participants are among the learners in Year nine to Year eleven at the school. All participants are English as second language (ESL) learners with Chinese, Tamil, and Arabic as their first languages.

The questionnaire is answered by all participants of the study. Data is gathered and analysed. Next, researchers randomly select 8 participants for an open-ended interview session. Participants are chosen based on their responses in the survey conducted.

\section{B. Research Instruments}

This study used a set of questionnaires to collect quantitative data to address the first research question. In addition, interview questions were used to collect qualitative data and further explore the ways that learners apply the strategies in their learning processes.

\section{1) Questionnaire}

Learners' LLS were elicited via Strategy Inventory of Language Learning (SILL), Version 7.0 (ESL/EFL) questionnaire. SILL is widely used and validated in different contexts worldwide to elicit strategy data on second/foreign language learning, including skills in acquiring vocabulary. The questionnaire comprises six parts, with each part representing the six language learning strategies adapted from Oxford [12]. The questionnaire includes a total of 50 statements with 5-point Likert scale response, with $1=\mathrm{Never}$ or almost never true (ANT), 2=Usually not true (UNT), $3=$ Somewhat true (ST), 4=Usually true (UT), and 5=Almost or almost always true (AAT) to indicate their level of agreement to various statements.

TABLE I. ALLOCATION OF ITEMS BASED ON LLS

\begin{tabular}{|c|c|}
\hline Items & Language learning strategy \\
\hline Part A: Q1-Q9 & Memory \\
\hline Part B: Q10-Q23 & Cognitive \\
\hline Part C: Q24-Q29 & Compensation \\
\hline Part D: Q30-Q38 & Metacognitive \\
\hline Part E: Q39-Q44 & Affective \\
\hline Part F: Q45-Q50 & Social \\
\hline 2) Interview questions
\end{tabular}

The interview questions are designed to further explore learners' ways of applying the LLS. Based on the survey findings, participants were expected to elaborate on the application of the strategies in their vocabulary learning. Participants' explanations should be based on the strategies suggested in the questionnaire. Two predetermined questions are developed by the researcher for this study.

TABLE II. INTERVIEW QUESTIONS

\begin{tabular}{|c|l|}
\hline 1 & $\begin{array}{l}\text { Out of the strategies suggested in the Cognitive strategy, } \\
\text { what are the strategies you used the most? }\end{array}$ \\
\hline 2 & $\begin{array}{l}\text { How do you apply the strategies in your vocabulary } \\
\text { learning? }\end{array}$ \\
\hline
\end{tabular}

\section{FINDINGS AND DISCUSSION}

\section{A. Overall Findings}

TABLE III. SUMMARY OF FINDINGS

\begin{tabular}{|c|c|c|c|}
\hline Language learning strategies & Mean & Level & Rank \\
\hline Memory & 3.22 & Moderate & 5 \\
\hline Cognitive & 3.58 & High & 1 \\
\hline Compensation & 3.43 & Moderate & 3 \\
\hline Metacognitive & 3.36 & Moderate & 4 \\
\hline Affective & 2.82 & Moderate & 6 \\
\hline Social & 3.44 & Moderate & 2 \\
\hline
\end{tabular}

Based on the table, the LLS with the highest mean is Cognitive strategy (3.58). The majority of the participants agree that Cognitive strategy is the most used LLS among good language learners of the international school. The second most common strategy is Social strategy with mean $=3.44$ and closely followed by Compensation strategy with mean $=3.43$. The Memory strategy has a mean of 3.22 and the Metacognitive Strategy at 3.36. The difference between the Memory and the Metacognitive strategy is very minimal. The least used or favoured strategy is the Affective strategy, where the mean is only 2.82 . From the 30 participants, many have voted on the Cognitive strategy as their most favourable strategy to improve their vocabulary list.

\section{B. The rank of Cognitive Strategies in Vocabulary Acquisition}

TABLE IV. ITEMS IN COGNITIVE STRATEGY

\begin{tabular}{|c|c|c|c|c|}
\hline Rank & No & Statement & Mean & Level \\
\hline 1 & B18 & $\begin{array}{c}\text { Watch TV shows } \\
\text { spoken in } \\
\text { English }\end{array}$ & 4.17 & \multirow{11}{*}{ High } \\
\hline 2 & B15 & $\begin{array}{l}\text { Look for words } \\
\text { in own language } \\
\text { that are similar to } \\
\text { new words in } \\
\text { English. }\end{array}$ & 3.90 & \\
\hline 3 & B13 & $\begin{array}{l}\text { Use words in } \\
\text { different ways. }\end{array}$ & 3.80 & \\
\hline 4 & B12 & $\begin{array}{c}\text { Practice the } \\
\text { sounds of words }\end{array}$ & 3.70 & \\
\hline 5 & B14 & $\begin{array}{c}\text { Start } \\
\text { conversation } \\
\text { with English } \\
\text { words }\end{array}$ & 3.63 & \\
\hline 6 & B19 & $\begin{array}{l}\text { Read an English } \\
\text { passage by } \\
\text { skimming, then } \\
\text { go back and read } \\
\text { carefully. }\end{array}$ & 3.60 & \\
\hline 7 & B10 & $\begin{array}{c}\text { Apply new } \\
\text { words several } \\
\text { times via } \\
\text { speaking and } \\
\text { writing skills }\end{array}$ & 3.57 & \\
\hline 8 & B17 & $\begin{array}{l}\text { Write notes, } \\
\text { messages, letters } \\
\text { or reports in } \\
\text { English. }\end{array}$ & 3.57 & \\
\hline 9 & B11 & $\begin{array}{l}\text { Attempt to talk } \\
\text { like native } \\
\text { speakers }\end{array}$ & 3.53 & \\
\hline 10 & $\mathrm{~B} 21$ & $\begin{array}{l}\text { Find the meaning } \\
\text { of English } \\
\text { sentences by } \\
\text { dividing it into } \\
\text { parts for easy } \\
\text { understanding. }\end{array}$ & 3.53 & \\
\hline 11 & B23 & Make summaries & 3.50 & \\
\hline
\end{tabular}




\begin{tabular}{|c|c|c|c|c|}
\hline & & $\begin{array}{c}\text { of information } \\
\text { heard or read in } \\
\text { English. }\end{array}$ & \multirow{2}{*}{ Moderate } \\
\hline 12 & B20 & $\begin{array}{c}\text { Try to find } \\
\text { anguage patterns } \\
\text { in the English } \\
\text { language }\end{array}$ & 3.30 & \multirow{2}{*}{} \\
\hline 13 & B16 & $\begin{array}{c}\text { Read English for } \\
\text { pleasure }\end{array}$ & 3.20 & \\
\hline 15 & B22 & $\begin{array}{c}\text { Try not to } \\
\text { translate word } \\
\text { for word. }\end{array}$ & 3.07 & High \\
\hline
\end{tabular}

Based on the table, there are 11 cognitive strategies that are most frequently used by the participants, with a high mean ranging from 3.50 to 4.50 . From the data, we can conclude that the participants mostly skim passage before rereading it, watch English tv shows and movies, use new words in different language skills, match similar words in English and their first languages, as well as practice the sounds of the words to sound like native speakers. Participants also divide English sentences into parts for easy understanding and summarize the information heard or read in English. Another item in the questionnaire that receives a considerably high mean (4.10) is Q29 in Compensation strategy, which states that participants substitute similar words and phrases when they have problems recalling certain words. The participants also try to speak like a native speaker and write notes and messages in English. From the research findings, we can conclude that most of the participants employed the cognitive strategies suggested by the questionnaire to improve their vocabulary.

\section{The Application of Cognitive Strategy in Vocabulary Learning}

Based on the data analysed from the questionnaire, 8 participants were selected for an open-ended interview. Participants shared their experiences in applying Cognitive strategy in vocabulary learning. Out of 11 cognitive strategies most frequently used by the participants, the interview revealed seven strategies that the participants consistently mention. Participants further discussed how these strategies were applied and their implication in the learners' vocabulary learning.

1) Watch TV shows spoken in English.

According to most participants, they build vocabulary by watching TV shows spoken in the target language. It is reported that they almost always watch foreign-language TV shows and movies with English subtitles. According to one of the participants, she has difficulty understanding spoken English words most of the time, especially when spoken by native speakers. However, having the English subtitles while watching TV shows helps her read and process the information more clearly. Another participant mentioned that reading subtitles while watching movies sometimes distracted him but it increased his understanding of the words delivered by the characters.

\section{2) Start Conversation in English}

Most of the participants agreed that they would start a conversation in English to improve their language proficiency. They also often use new vocabulary during the conversation with their friends. Starting conversation among friends is more casual and makes them less anxious than using the language with adults (i.e., teachers, strangers). The majority reported that by practicing the target language in spoken communication, they learned new English words and gained the confidence to use the target language. One participant revealed that he practiced using new vocabulary in sentences by talking to himself. He recorded himself and reviewed it to see his progress.

\section{3) Write Notes, Messages, Letters, or Reports In English}

All 8 participants support the strategy of using vocabulary in writing as a practice to enhance language proficiency. One participant explained that she likes to pay attention to vocabulary in novels and storybooks as inspiration for her writing assignment. She will jot down the vocabulary that she found from novels and try using the words in her essay. According to the participant, it works well with narrative essays where she tries using bombastic words. Another participant mentioned that she likes writing her diary using English even though it is not her mother tongue. She has been consistently writing her diary in English for a few years, and it helps improve her language proficiency and writing skills.

4) Look for Words in Own Language that are Similar to New Words in English

Even though direct translation or translation of word-byword is not encouraged to be used in productive skills such as speaking and writing, the strategy may help learners in receptive skills, such as reading, as participants stated that it helps them understand English words quicker. 7 out of 8 participants actively translate newly learned words into their mother tongues for quicker understanding. According to one participant, translating new words into her mother tongue (Malay language) is easier for her to understand, and the strategy is often used during communication. Another girl mentioned that using 'Google Translate' is better and quicker than finding word meanings in the dictionary. However, researchers argue that this strategy helps learners understand words quicker but not necessarily better based on the responses received. Some words are incomparable between two languages and may not translate as accurately as they would hope.

5) Apply New Words Several Times Via Speaking and Writing Skills

All participants agree that they practice English vocabulary by using new words in their writing and speaking. Several participants acknowledged this strategy used to practice 'putting the words in context' to remember better. The practice also strengthens their memory and understanding of the acquired vocabulary. However, some of them also admitted to being anxious about making mistakes and being laughed at when they stutter.

Several participants reported that they also use social media as platforms to practice the target language. The majority of the participants leave comments, write tweets and statuses on social media such as Facebook, Instagram, and Twitter in English. They also make friends with people all around the globe and use English as the medium of communication. Researchers concluded that social media is an effective medium for learners to practice the target language as it is less hostile. Participants were less afraid of making mistakes when typing words in English instead of using the words in spoken communication.

\section{6) Attempt to Talk Like Native Speakers}

Most learners mentioned that they watched the series on Netflix. Therefore, the language spoken by the actor or the actresses is native English. The learners take this opportunity to listen to their pronunciation and practice speaking the new words learned in the classroom or with their friends. The 
learners also mentioned that when they hear songs, they look upon details in sounds and syllabus to ensure they speak a proper language. Since the learners plan to move to Englishspeaking nations, they must have proper speaking skills and pronunciation. The learners also compare the words spoken by them and their friends to broaden their vocabulary. If they are unsure of a word, they look upon their educators to correct them.

\section{7) Writing Messages in English}

Learners mentioned that they often use social media to communicate with their friends. Most of them make it a habit to message one another using the English language on social media. Learners also mentioned that the autocorrect or spelling suggestion in their keyboard is extremely useful as they are exposed to the actual spelling. Within six months, they noticed that they have improved and can use more vocabularies in communication with the assistance of the keyboard's spelling suggestion and the 'autocorrect.' The learners also mentioned writing and sending notes in English had improved their confidence in speaking English in a crowded place.

\section{CONCLUSION, IMPLICATIONS, AND RECOMMENDATIONS}

The paper aims to identify the LLS employed by learners of an international secondary school in improving their vocabulary. Findings revealed cognitive strategy as the preferred LLS among the participants. The least preferred and used strategy is the affective strategy. Other than that, the participants shared their application for cognitive strategies in vocabulary learning. The five main strategies to the cognitive approach discussed are

The results derived from the study may contribute to several parties. Firstly, the participants are more informed on LLS in general and their favoured strategy, especially in English vocabulary development. Learners will be able to continue discovering LLS and employ them in other language skills, such as reading, writing, and speaking. It will also increase the public's awareness of language learning strategies, especially to teachers and learners. Learners may foster various strategies to improve their learning performance. Besides, using LLS encourages learners to make choices regarding their learning which engages them in their learning progress and incidentally shapes them to become autonomous learners. Learners generally do better on assignments that match their learning styles. Thus, teachers who recognize learners' preferred LLS may plan lessons and activities suitable to learners' strategies and styles.

Moreover, researchers also found that participants are also triggered by intrinsic motivation apart from using suitable strategies. The cognitive strategy such as speaking as native speakers and checking on pronunciation styles are part of intrinsic motivation. International school learners motivate themselves by looking upon other international learners as well. The motivation allows them to perform better at school and improves themselves in their English classroom.

For future research, researchers can do more profound research on second language students' cognitive strategy styles or how teachers can impose cognitive strategy when teaching the learners.

\section{REFERENCES}

[1] E.J. Nejati, A, The effect of using computer-assisted language learning (CALL) on Iranian EFL learners' vocabulary learning: An experimental study, Cypriot Journal of Educational Sciences 13 (2018) 113-124.

[2] Z.M.H. Baharudin, Receptive Vocabulary Knowledge or Productive Vocabulary Knowledge in Writing Skill, Which One Important?, International Journal of Academic Research in Business and Social Sciences 6 (2016) 261-271.

[3] A.N. Ashrafzadeh, V, Vocabulary Knowledge: Malaysian Tertiary Level Learners' Major Problem in Summary Writing, Journal of Language Teaching and Research 6 (2015) 286.

[4] M. Alqahtani, The importance of vocabulary in language learning and how to be taught, International Journal of Teaching and Education 3 (2016) 21-34.

[5] H.O.N.A.A. Manan, 2015. A Study Of Language Learning Strategies ( LLS ) Used By ESL Learners Of An Urban Secondary School in Perak. In Constructing Contemporary Malaysia: Insight From Research Effort, Perak: Unit for Research and Intellect Application, UITM (2015) 1-10.

[6] P.I. Martínez, The importance of language learning strategies in foreign language teaching, Cuadernos de filología inglesa 5 (1996) 503.

[7] S. Sener, Vocabulary learning strategy preferences and vocabulary size of pre-service English teachers, International Journal of Educational Researchers 6 (2015) 15-33.

[8] S.S.A.H.A.R. Nor Hazwani Munirah Lateh, Receptive Vocabulary Levels of Malaysian University Students, LSP International Journal 5 (2018) 105-113.

[9] M.A. Noor Zainab Abdul Razak \& Babikkoi, English Language Learning Strategies of Malaysian Secondary School Students: Implication for Inter-Cultural Communication, Sociology Mind 4 (2014) 206-212.

[10] N.A.Z. Abidin, Computer-based interactive games as learning aids, The English Teacher 40 (2011) 85-94.

[11] J.L. Mohamed Amin, \& Mohd Isa Hamzah, Language learning strategies used by secondary school students in Malaysia, Jurnal Pendidikan 26 (2001) 3-20.

[12] R. Oxford, Language learning strategies: What every teacher should know, Boston: Newbury House, 1990).

[13] A. Susanto, Ab Halim, F. \& Nuwrun, S, Vocabulary learning strategies, vocabulary skills, and integrative motivation levels among university students, International Journal of Engineering and Advanced Technology 8 (2019) 323-334.

[14] L. Cameron, Teaching languages to young learners (Cambridge: Cambridge University Press, 2001).

[15] P. Zare, Language learning strategies among EFL/ESL learners a review of literature, International Journal of Humanities and Social Science 2 (2012) 162-169.

[16] K.S.M. Teh, Embi, M. A., Yusoff, N. M. R. N. \& Mahamod, Z, A closer look at gender and Arabic language learning strategies used, European Journal of Social Sciences 9 (2009) 399-407.

[17] H.D. Sewell, The good language learner. Retrieved from Second Language Acquisition: http://www.cels.bham.ac.uk/resources/essays/Sewell_SL A.pdf, (2013).

[18] R.B.O. Johnson, A. J, Toward a Definition of Mixed Methods Research, Journal of Mixed Methods Research 1 (2007) 112-133. 
